\title{
PELAKSANAAN EKSEKUSI OBJEK JAMINAN FIDUSIA BERDASARKAN TITLE EKSEKUTORIAL
}

\author{
Benny Krestian Heriawanto \\ Fakultas Hukum Universitas Islam Malang \\ Jl. MT Haryono Nomor No. 193, Malang, Jawa Timur, Indonesia \\ E-mail : bennyheriawanto@unisma.ac.id
}

\begin{abstract}
The existence of collateral institutions is very important for creditors particularly to provide certainty over the fulfillment of their rights. In Indonesia there are several collateral institutions, one of which is fiduciary, as a collateral institution, fiduciaries have advantages and disadvantages, especially in carrying out executions, therefore it is necessary to know how the execution of fiduciary collateral objects, especially executions that are based on executorial titles. This paper is based on normative juridical research, with a legal and conceptual approach. According to the research it can be concluded that based on the provisions of article 30 of the Fiduciary Law, with an executorial title, the creditor is given the right to repossess so that the creditor can directly take the object of fiduciary collateral.
\end{abstract}

\section{Keywords : Fiduciary, Execution, The Right to Reposses}

\begin{abstract}
Abstrak
Keberadaan lembaga jaminan sangat penting bagi kreditur khususnya untuk memberikan kepastian atas terpenuhinya hak yang dimilikinya. Di Indonesia terdapat beberapa lembaga jaminan, salah satunya adalah fidusia, sebagai lembaga jaminan, fidusia memiliki kelebihan dan kekurangan, khususnya dalam pelaksanaan eksekusi, oleh karenanya perlu diketahui bagaimana pelaksanaan eksekusi objek jaminan fidusia khususnya ekesekusi yang didasarkan pada title eksekutotial. Tulisan ini disusun berdasarkan penelitian yuridis normatif, dengan pendekatan peraturan perundangan-undangan dan konseptual. Berdasarkan penelitian dapat disimpulkan bahwa berdasarkan ketentuan Pasal 30 Undang undang Fidusia, dengan title ekeskutorial, kepada kreditur diberikan the right to reposses sehingga dengannya kreditur dapat mengambil objek jaminan fidusia secara langsung.
\end{abstract}

Kata Kunci : Fidusia, Eksekusi, The Right to Reposses

\section{A. PENDAHULUAN}

Kredit sebagai suatu istilah tidak lagi asing didengar oleh masyarakat, kredit tidak saja dikenal oleh masyarakat yang berpendidikan tinggi namun juga oleh mereka yang 
berpendidikan rendah. Berdasarkan sejarah dapat diketahui bahwa penggunaan istilah kredit diambil dari bahasa Yunani "credere" yang diartikan sebagai kepercayaan, sehingga tidak salah jika dalam praktek pemberian utang piutang sebagai prestasi kreditur dan kontra prestasi debitur di masa mendatang mempersyaratkan kepercayaan. Kepercayaan terhadap kemampuan debitur untuk dapat meberikan kontra prestasi (dalam utang piutang dipahami sebagai prestasi berupa mengembalikan uang yang diutang). ${ }^{1}$

Kredit modern ini memiliki beberapa tujuan, yakni pertama untuk memberikan keuntungan kepada kreditur yang diperoleh melalui bunga dalam perjanjian kredit konvensional atau dalam bentuk margin dalam perjanjian pembiayaan, disisi yang lain keuntungan juga diperoleh oleh nasabah khususnya jika kredit ditujukan untuk menopang keberlangsungan usaha debitur (kredit dilakukan guna kepentingan investasi pengembangan perluasan dan pengembangan usaha debitur), atau minimal secara umum dengan kredit debitur dapat dengan mudah memperoleh benda yang dibutuhkan, kedua bertujuan untuk mendorong pembangunan nasional di berbagai sektor, dengan kredit akan meningkatkan jumlah penerimaan pajak, membuka atau memperluas lowongan kerja, meningkatkan jumlah barang dan jasa yang dibutuhkan oleh masyarakat, meningkatnya jumlah devisa dan lain sebagainya. $^{2}$

Atas besarnya peran kredit terhadap masyarakat dan pembangunan nasional, maka seyogyanyalah jika kredit mendapat perhatian dari Pemerintah, dan Negara Indonesia sebagai negara hukum, wajib membentuk hukum yang mengakomodir kepentingan tersebut, hukum yang bekerja secara preventif untuk mencegah terjadinya hal hal yang merugikan dan sekaligus secara restitutif bekerja untuk menyeimbangkan harmoni masyarakat yang terganggu atau bahkan hukum yang secara represif dapat memberikan efek jera terhadap orang yang melakukan pelanggaran hukum.

Dalam kajian hukum perdata dikenal hak kebendaan yang sifatnya memberikan jaminan dan secara khusus menjadi objek kajian hukum jaminan, dalam hukum perikatan perjanjian yang berkaitan dengan jaminan dipahaminya sebagai perjanjian yang bersifat accesoir, perjanjian tambahan yang diperjanjikan untuk mem-back up kepastian kontra prestasi yang diperjanjikan dalam perjanjian utama, dan karena sifatnya dwingen recht maka hukum jaminan yang mengatur pokok pokok dari perjanjian accesoir harus mampu memberikan kepastian atas terwujudnya kontra prestasi tersebut.

Kepastian hukum yang terkandung dalam hukum jaminan yang secara pokok mengatur hal hal yang berkaitan dengan perjanjian accesoir akan turut menentukan terhadap terwujudnya tujuan kredit sebagai perjanjian utama, demikian pula atas kepentingan seorang kreditur dalam perjanjian utama akan sangat bergantung pada kemampuan hukum jaminan dalam memberikan kepastian atas perlindungan hak hak yang dimiliki oleh kreditur. Hal ini

${ }^{1}$ Thamrin Abdullah, Francis Tantri, 2002. Bank dan Lembaga Pembiayaan, Rajagrafindo Persada, Jakarta. Hlm. 162.

${ }^{2}$ Ibid. hlm. 166-167. 
disadari karena dengan sifatnya yang dwingen recht tidak memberikan kesempatan kepada para pihak dalam perjanjian untuk memperjanjikan hal hal yang tidak diatur dalam hukum jaminan, asas kebebasan berkontrak hanya bekerja untuk menentukan jenis hukum jaminan yang bekerja guna melindungi kepentingannya.

Hukum jaminan telah menawarkan alternatif lembaga jaminan yang dapat dipilih guna mengakomodir kebutuhan dan kepentingan para pihak, hukum jaminan yang telah berevolusi berubah mengikuti perubahan sosial, namun walau demikian di dalam praktek diketahui terdapat permasalahan yang timbul darinya, hingga lembaga jaminan sebagai produk hukum tidak lagi memberikan kepastian khususnya untuk memberikan perlindungan hukum bagi kreditur.

Salah satu lembaga jaminan yang dikenal dalam lembaga jaminan adalah fidusia, secara khusus diatur dalam Undang undang Nomor 42 Tahun 1999 tentang Jaminan Fidusia. Berdasarkan ketentuan Pasal 1 butir 2 Undang undang Nomor 42 Tahun 1999 tentang Jaminan Fidusia diartikan sebagai hak jaminan atas benda bergerak baik yang berwujud atau yang tidak berwujud dan benda bergerak khususnya bangunan yang tidak dapat dibebani Hak Tanggungan sebagaimana dimaksud dalam Undang undang Nomor 4 Tahun 1996 tentang Hak Tanggungan yang tetap berada dalam kekuasaan pemberi fidusia, sebagai agunan bagi pelunasan utang tertentu, yang memberikan kedudukan yang diutamakan kepada penerima fidusia terhadap kreditur lainnya.

Atas pemahaman tersebut dapat dipahami bahwa yang menjadi objek dari jaminan fidusia salah satunya adalah benda bergerak baik berwujud dan tidak berwujud, dan karena sifatnya maka dapat dipastikan benda tersebut sebagai jaminan tidak akan menetap dalam satu tempat. Objek jaminan fidusia yang salah satunya adalah benda bergerak akan sangat mudah dialihkan bahkan dengan cara melawan hukum.

\section{B. RUMUSAN MASALAH}

Rumusan masalah dalam penelitian ini adalah bagaimana mekanisme penyelesaian kredit macet dengan pelaksanaan eksekusi objek jaminan fidusia.

\section{METODE PENELITIAN}

Tulisan ini disusun dengan metode yuridis normatif, dengan pendekatan peraturan perundang-undangan, dan konseptual, atas pendekatan tersebut digunakan beberapa bahan hukum primer yakni peraturan perundang-undangan yang relevan dengan objek kajian khususnya Undang-undang Nomor 42 Tahun 1999 tentang Jaminan Fidusia yang didukung dengan bahan hukum sekunder berupa buku buku yang memuat penjelasan yang berkaitan secara konseptual dan teoritis dengan objek kajian, dan guna menemukan jawaban atas isu 
hukum yang diangkat maka interpretasi gramatikal dan teleologis digunakan sebagai salah satu teknik analisis bahan hukum.

\section{PEMBAHASAN}

Fidusia merupakan salah satu hak kebendaan yang bersifat memberikan jaminan atas terpenuhinya hak hak yang dimiliki kreditur dalam perjanjian pokok, dan fidusia sebagai sebuah perjanjian merupakan perbuatan hukum yang dinyatakan tunduk pada ketentuan Buku Ke III Kitab Undang undang Hukum Perikatan tentang Perikatan (verbintenis), oleh karena itu segala ketentuan yang berkaitan dengan perjanjian fidusia berlaku ketentuan umum yang mengatur tentang perikatan dan perjanjian pada umumnya.

Perjanjian sebagai salah satu dari peristiwa hukum merupakan salah satu dari sumber perikatan, selain perjanjian terdapat ketentuan undang undang yang dapat pula melahirkan sebuah perikatan. Perikatan dalam pengertian ini oleh Subekti diartikan sebagai suatu hubungan hukum antara dua orang atau dua pihak, berdasarkan mana yang satu berhak menuntut sesuatu hal dari pihak lainnya, dan pihak yang lain wajib untuk memenuhi tuntutan tersebut. Serupa dengan pengertian tersebut Pitlo juga memberikan definisi perikatan sebagai suatu hubungan hukum yang bersifat harta kekayaan antara dua orang atau lebih, atas dasar mana pihak yang satu berhak (kreditur) dan pihak lain berkewajiban (debitur) atas suatu prestasi. $^{3}$

Fidusia sebagai lembaga jaminan merupakan lembaga yang lahir guna menyempurnakan kekurangan kekurangan yang terdapat dalam lembaga jaminan lain yang telah dikenal sebelumnya, berdasarkan sejarah dapat dipahami bahwa fidusia telah lama dikenal bahkan sejak jaman Romawi, yang diberlakukan berdasarkan hukum yang tidak tertulis. Pada jaman ini jaminan fidusia dibedakan menjadi 2 macam yaitu fidusia cum creditore dan fidusia cum amico yang lahir dari perjanjian yang disebut dengan pactum fiduciae yang diikuti dengan penyerahan hak atau in iure cessio. Fiducia cum creditore contracta secara bahasa diartikan sebagai janji kepercayaan yang dibuat oleh kreditur, sedangkan secara istilah adalah perjanjian yang dilandaskan pada kepercayaan bahwa kreditur akan mengalihkan kembali kepemilikan atas benda kepada debitur, setelah debitur mengalihkan kepemilikan atas benda sebagai jaminan utang dan membayar lunas kepada kreditur atas utang yang telah diperjanjikannya. Sedangkan fiducia cum amico contracta secara diartikan sebagai janji kepercayaan yang dibuat dengan teman, perjanjian ini berbeda dengan jenis fidusia yang pertama merupakan fidusia yang diperjanjikan bukan sebagai lembaga jaminan, namun memiliki kemiripan dengan fidusia yang pertama karena terdapat unsur fides atau trust di dalamnya.

\footnotetext{
${ }^{3}$ P.N.H. Simanjuntak, 2009, Pokok pokok Hukum Perdata Internasional, Djambatan, Jakarta. Hlm.
} 318-319. 
Fiducia cum amico merupakan perjanjian yang serupa dengan perjanjian penitipan barang yang beralihnya sebuah benda dilakukan untuk kepentingan pemilik benda, namun yang membedakannya dengan perjanjian penitipan benda pada fidusia jenis ini diikuti dengan peralihan kepemilikan diikuti janji teman yang tersebut akan mengembalikan kepemilikan benda tersebut jika pihak pemilik yang semula menghendakinya.

Dalam burgerlijk Wetboek fidusia sebagai lembaga jaminan tidak dikenal, nampaknya orang Belanda tidak meresepsi fidusia sebagai lembaga jaminan selain fidusia dan hipotek. Namun dalam perkembangannya keberadaan lembaga jaminan hipotek dan gadai tidak dianggap cukup untuk mengatasi permasalahan yang timbul pada masa itu, hipotek atas tanah tidak banyak diminati dan gadai diakuinya memiliki kelemahan sehingga menyulitkan bagi pemilik jaminan.

Pasal 1152 ayat 2 Kitab Undang undang Hukum Perdata menetapkan agar objek jaminan gadai berada dibawah penguasaan penerima gadai, Pasal 1152 ayat 2 Kitab Undang undang Hukum Perdata menegaskan bahwa penguasaan objek jaminan oleh penerima gadai menjadi syarat keabsahan perjanjian gadai.

Tak sah adalah hak gadai atas segala benda yang dibiarkan tetap dalam kekuasaan ini si berutang atau si pemberi gadai, ataupun yang kembali atas kemauan si berpiutang. Sedangkan hipotek berdasarkan peraturan perundang-undangan membatasi objeknya terbatas pada benda yang tidak bergerak baik karena sifat, tujuan dan karena ketentuan peraturan perundangundangan.

Guna mengatasi permasalahan tersebut maka diperjanjikan jual beli antara pemberi kredit dan penerima kredit dengan syarat pemberi kredit bersedia untuk menjual kembali objek jual beli setelah kredit telah dibayar lunas. Objek jual beli dipersyaratkan pula harus tetap berada di bawah penguasaan pemberi kredit dalam kedudukannya sebagai peminjam pakai, kebiasaan ini kemudian dibenarkan oleh Hoge Raad (Mahkamah Agung Belanda) walau terdapat perbedaan pendapat di kalangan para ahli, namun dengan dikuatkannya kebiasaan tersebut dalam sebuah putusan ditingkat kasasi maka hal tersebut melahirkan pranata jaminan dengan penyerahan hak milik secara kepercayaan yang dikenal kemudian dengan istilah fidusia. ${ }^{4}$

Di Indonesia praktek fidusia telah dikenal sejak jaman Hindia Belanda hal ini terlihat dari putusan Hooggerechtsh of (HGH) tertanggal 18 Agustus 1932, dan di dalam praktek hukum adat dikenal hal yang serupa dengan fidusia, perjanjian gadai tanah dimana permberi gadai diperjanjikan tetap menguasasi tanah yang digadaikan dengan perjanjian bagi hasi bagi petani penggarap (pemberi gadai) dan penerima gadai sebagaimana jamak ditemukan dan dilakukan oleh masyarakat Suku Osing. ${ }^{5}$

${ }^{4}$ Gunawan Widjaja dan Ahmad Yani, 2000, Seri Hukum Bisnis Jaminan Fidusia, Rajawali Pers, Jakarta. Hlm. 113-118.

${ }^{5}$ Dominikus Rato, 2009. Dunia Hukum Orang Osing, LaksBang Mediatama, Yogyakarta. Hlm. 168. 
Melalui konsideran Undang undang Nomor 42 Tahun 1999 tentang Fidusia dapat dipahami bahwa sekian lama lembaga jaminan fidusia berlaku hanya di dasarkan pada yurisprudensi dan tidak ada satupun peraturan perundang-undangan yang mengaturnya.

Saat ini keberadaan sebagai lembaga jaminan diatur secara khusus dalam peraturan perundang undangan setingkat undang undang, Undang undang Nomor 42 Tahun 1999 tentang Fidusia yang berlaku sejak tanggal 30 September 1999.

Fidusia sebagai lembaga jaminan terus mengalami perkembangan dan secara praktis banyak diperjanjikan oleh masyarakat walau dalam bentuk yang berbeda, dimana berdasarkan hukum Romawi pemegang jaminan dinyatakan sebagai pemilik objek jaminan sedangkan penerima jaminan pada saat ini hanya dipahaminya sebagai pemegang jaminan saja. Pada mulanya fidusia hanya mengenal objek jaminan berupa benda yang bergerak, namun saat ini seiring dengan berlakunya Undang undang Nomor 42 Tahun 1999 tentang Jaminan Fidusia, fidusia mengenal benda tetap (tidak bergerak) sebagai objek jaminan.

Menurut Pasal 1 butir 1 Undang undang Nomor 42 Tahun 1999 tentang Jaminan Fidusia, fidusia adalah pengalihan hak kepemilikan suatu benda atas dasar kepercayaan dengan ketentuan bahwa benda yang hak kepemilikannya dialihkan tersebut tetap dalam penguasaan pemilik benda.

Sedangkan menurut A. Hamzah dan Senjun Manulang sebagaimana dikutip oleh Salim HS, fidusia adalah Suatu cara pengoperan hak milik dari pemiliknya (debitur dalam perjanjian pokok) berdasarkan perjanjian utang piutang kepada kreditur, akan tetapi yang diserahkan hanya haknya saja secara yuridise-levering dan hanya dimiliki oleh kreditur secara kepercayaan saja (sebagai jaminan utang debitur), sedangkan barangnya tetap dikuasai oleh debitur, tetapi bukan sebagai eigenar maupun sebagai bezitter, melainkan hanya sebagai detentor atau houder dan atas nama kreditur-eigenar. ${ }^{6}$

Berdasarkan pengertian tersebut di atas, fidusia merupakan lembaga yang melahirkan hubungan hukum yang lahir karena adanya perbuatan pengoperan/pengalihan hak milik, namun tidak diikuti dengan pengoperan/pengalihan kekuasaan atas benda, pengoperan/pengalihan mana disertai dengan kepercayaan jika tujuan perjanjian telah tercapai maka pihak yang menerima pengalihan akan mengembalikan kembali objek fidusia pada pihak yang mengalihkan, sehingga karenanya dapat dinyatakan penerima pengalihan tidak dapat disebut sebagai eigenar/bexitter namun hanya dapat disebut sebagai houder/detentor.

Atas kedudukannya sebagai houder/detentor penerima pengoperan/ pengalihan dilarang untuk mengalihkan kepemilikannya kepada pihak lain kecuali telah diperjanjikan untuk itu/dipenuhinya sebab untuk dialihkan. Pengoperan/pengalihan tersebut diawali dengan perjanjian pokok yang pada umumnya berupa perjanjian utang piutang. Namun walau demikian dalam kepentingannya dengan eksekusi, objek jaminan fidusia berdasarkan peraturan perundang-undangan berada di bawah kekuasaan debitur, dan mengingat bahwa

\footnotetext{
${ }^{6}$ H. Salim, HS, 2004, Perkembangan Hukum Jaminan DI Indonesia, Rajagrafindo, Jakarta. Hlm. 56.
} 
objek jaminan fidusia berupa benda yang bergerak maka bukanlah hal yang tidak mungkin jika objek jaminan fidusia tidak dapat dieksekusi oleh kreditur.

Eksekusi merupakan langkah akhir yang dapat diambil oleh kreditur pada saat debitur diyakini tidak lagi memiliki kemampuan dan/atau iktikad baik untuk menyelesaikan kewajibannya membayar kredit. Pembayaran yang seharusnya dibayarkan secara berlaka tidak dilakukan oleh debitur. Dalam praktek ditemukan beberapa sebab/alasan tidak lancarnya kredit (kredit macet) yang seharusnya dipenuhi oleh debitur, salah satunya disebabkan oleh meningkatnya kebutuhan yang tidak terduga dalam keluarga dan menjadi tanggungan debitur, gagalnya usaha sebagai sumber pendapatan utama bagi debitur dan/atau keluarga, atau salah salah satunya diketahui sebab debitur tidak memiliki iktikad baik untuk membayar kredit sesuai dengan perjanjian yang telah disepakati. Atas sebab/alasan yang berbeda tersebut kreditur pada umunya memiliki cara penyelesaian kredit macet atau cara eksekusi yang berbeda.

Terdapat beberapa cara penyelesaian kredit macet/eksekusi yang dapat ditempuh oleh kreditur, antara lain:

1. Kreditur mengajukan kesepakatan baru dengan mekanisme restrukturisasi kredit (novasi objektif). Dengan retrukturisasi kreditur dan debitur memperhitungkan kembali sisa hutang debitur untuk ditetapkan kembali menjadi hutang pokok baru, dan atas hutang pokok baru tersebut kemudian disepakati pula jangka waktu (tenor) masa pelunasan dan nilai cicilan baru yang harus dibayarkan oleh debitur dalam periode tertentu.

2. Selain dengan jalan restrukturisasi karena alasan ketiadaan kemampuan debitur untuk memenuhi kewajibannya, maka penyelesaian kredit macet dilakukan dengan penyerahan secara sukarela objek jaminan fidusia yang diikuti dengan penjualan objek jaminan fidusia secara di bawah tangan, alternatif ini diambil jika diketahui konsumen/nasabah debitur sama sekali tidak lagi memiliki kemampuan untuk melaksanakan kewajiban (membayar angsuran), dan debitur tetap mengharapkan agar objek jaminan dapat terjual dengan harga yang maksimal. Atas alternatif ini lembaga pembiayaan menentukan prosedur agar proses penjualan objek jaminan fidusia secara di bawah tangan dan termasuk di dalamnya proses peralihan kepemilikan objek jaminan fidusia dilakukan dengan melibatkan lembaga pembiayaan, secara teknis setelah nasabah menyepakati dengan collector atas penjualan di bawah tangan, maka konsumen/debitur diberikan kesempatan untuk menemukan pembeli, dan atas pembayaran yang dilakukan oleh pembeli digunakan sebagai pelunasan atas tanggungan (kewajiban) debitur terhadap kreditur.

3. Penyerahan secara sukarela atau eksekusi objek jaminan fidusia diikuti dengan penjualan di muka umum (lelang), atas penyelesaian ini penjualan di muka umum (lelang) dapat dilakukan melalui dua mekanisme yakni penjualan di muka umum (lelang) yang dilakukan melalui perusahaan yang ditugaskan untuk menyelanggarakan penjualan di 
muka umum (lelang) atau penjualan di muka umum yang dilakukan oleh lembaga pembiayaan. $^{7}$

4. Pengalihan hak atas piutang juga dijamin dengan fidusia yang mengakibatkan beralihnya demi hukum segala hak dan kewajiban penerima fidusia kepada Kreditur baru, upaya penyelesaian ini diatur dalam Pasal 19 Undang undang Nomor 42 Tahun 1999 tentang Jaminan Fidusia jo. Pasal 1400 - Pasal 1403 Kitab Undang undang Hukum Perdata. Tindakan ini menyebabkan hapusnya perikatan di antara kreditur lama dengan debitur namun beralih kepada kreditur baru, yang dengan beralihnya perikatan yang diperjanjikan dari kreditur lama kepada kreditur baru menyebabkan turut beralih pula segala hak turunan atas hak diperjanjikan dalam perjanjian pokok (utang piutang); ${ }^{8}$

Penyelesaian kredit melalui cara ini pada umumnya diikuti dengan proses pendaftaran pengalihan hak di Kantor Pendaftaran Fidusia, pendaftaran dilakukan untuk melaporkan perubahan data sebagaimana dimaksud dalam Pasal 13 Undang undang Nomor 42 Tahun 1999 tentang Jaminan Fidusia.

Hal yang paling prinsip untuk dipahami oleh kreditur adalah pelaksanaan eksekusi berdasarkan title eksekutorial adalah syarat sahnya title eksekutorial. Title eksekutorial demi hukum lahir setelah lembaga jaminan fidusia dianggap lahir, dan jaminan fidusia demi hukum lahir serta memberikan kedudukan yang diutamakan setelah lembaga fidusia didaftarkan, atas ketentuan tersebut terdapat beberapa ketentuan dalam Undang undang Nomor 42 Tahun 1999 tentang Jaminan Fidusia yang relevan dengan lahir dan dilaksanakannya title eksekutorial, antara lain:

1. Perjanjian fidusia harus dituangkan dalam akta yang dibuat oleh Notaris sebagaimana diatur dalam Pasal 5 ayat 1 Undang undang Nomor 42 Tahun 1999 tentang Jaminan fidusia;

2. Akta jaminan fidusia yang telah dibuat dengan akta Notaris wajib didaftarkan di Kantor Pendaftaran Fidusia, sebagaimana diatur dalam Pasal 11 ayat 1 Undang undang Nomor 42 Tahun 1999 tentang Jaminan Fidusia;

3. Pelaksanaan eksekusi didasarkan pada ketentuan Pasal 29 Undang undang Nomor 42 Tahun 1999 tentang Jaminan Fidusia, yang mempersyaratkan pemberi fidusia (debitur) dalam keadaan cidera janji sebagaimana diatur dalam Pasal 1243 Kitab Undang undang Hukum Perdata, debitur dalam keadaan lalai tidak memenuhi prestasi atau debitur tidak melaksanakan prestasi dalam jangka waktu yang telah ditentukan/disepakati dalam perjanjian pokok dan/atau telah dianggap wanprestasi berdasarkan kesepakatan yang dibuat dan dituangkan dalam perjanjian pokok.

${ }^{7}$ Benny K. Heriawanto, Isdiyana Kusuma Ayu, 2018, Efektivitas Perlindungan Hukum Pihak Pihak Dalam Pelaksanaan Eksekusi Objek Fidusia Di Kota Malang, Laporan Hasil Penelitian Program Hibah Institusi UNISMA (Hi-Ma), Lembaga Penelitian dan Pengabdian Kepada Masyarakat Universitas Islam Malang, Malang.

8 Pengadilan Negeri Bekasi, http://pn-bekasikota.go.id/2015-06-06-01-33-28/eksekusi-jaminan.html diakses pada tanggal 22 Juni 2019. 
Dengan title eksekutorial terdapat kemudahan yang diberikan oleh undang undang kepada penerima fidusia (kreditur), dengan the right to reposses penerima fidusia (kreditur) diberikan wewenang untuk mengambil objek jaminan fidusia dari tangan pemberi fidusia (debitur), jika diketahui pemberi fidusia (debitur) tidak bersedia menyerahkan objek jaminan fidusia.

M. Yahya Harahap menjelaskan bahwa the right to reposses diberikan oleh undang undang kepada penerima fidusia (kreditur) dalam kedudukan dan kapasitasnya sebagai legal owner dan economiz owner atas objek jaminan fidusia, atau secara bersama sama dengan pihak berwenang (pihak kepolisian berdasarkan Peraturan Kepala Polisi Republik Indonesia Nomor 8 Tahun 2011 tentang Pengaman Eksekusi Jaminan Fidusia atau pihak Pengadilan Negeri berdasarkan ketentuan Pasal 200 HIR) melakukan eksekusi atas objek jaminan fidusia. $^{9}$

Dengan title eksekutorial yang memberikan kepada kreditur the right to reposses akan mempermudah pelaksanaan eksekusi objek jaminan fidusia, walau disadari bahwa dengan title eksekutorial yang terkandung di dalamnya the right to reposses tidak selalu dapat menyelesaikan kredit macet, karena eksekusi tidak dapat dilaksanakan (noneksekutabel) karena beberapa sebab/alasan.

Salah satu alasan tidak dapat dijalankannya eksekusi atas objek jaminan fidusia adalah karena harta kekayaan sebagai objek jaminan fidusia tidak ada baik secara permanen misalnya musnah karena bencana alam berupa gempa, kebakaran, banjir atau lainnya atau secara temporer objek jaminan fidusia tidak diketahui keberadaannya karena telah dialihkan kepada pihak lain oleh debitur secara melawan hukum. Namun tentu keadaan ini tidak pula menghapuskan hak yang dimiliki oleh kreditur, jika pada suatu saat kreditur mengetahui atas keberadaan objek jaminan fidusia maka kreditur dapat kembali melaksanakan eksekusinya kecuali atas objek jaminan fidusia yang dinyatakan musnah secara permanen, sehingga pengawasan secara intens oleh kreditur atas objek jaminan fidusia menjadi sebuah keharusan guna terwujudnya kepastian eksekusi objek jaminan fidusia.

Hukum sebagai sebuah instrumen telah bekerja untuk memberikan perlindungan hukum kepada pihak yang lemah khususnya dalam perjanjian utang piutang yang diikuti dengan perjanjian jaminan fidusia adalah pihak kreditur/penerima fidusia. Secara umum dapat kita pahami bahwa kreditur memiliki kedudukan yang kuat dalam perjanjian utang piutang pada tahap pra kontraktual dan kontraktual, namun pada tahap post kontraktual (pada masa pelaksanaan perjanjian) kreditur sebaliknya berada dalam posisi yang lemah, kreditur memiliki risiko tidak memperoleh hak piutangnya, sebab debitur tidak memenuhi kewajiban mengembalikan utangnya, untuk itu lembaga jaminan dibutuhkan.

Kemudahan dalam proses eksekusi objek jaminan melalui title eksekutorial dengan the right to reposses merupakan wujud konkrit dari cara kerja hukum untuk mengembalikan

${ }^{9}$ M. Yahya Harahap, 2009, Ruang Lingkup Permasalahan Eksekusi Bidang Perdata, Edisi Kedua, Sinar Grafika, Jakarta. Hlm. 215. 
kedudukan kreditur dan debitur yang tidak seimbang menjadi seimbang, karena sejatinya hukum dibentuk untuk mewujudkan kepastian hukum, dengan tanpa mengabaikan aspek kemanfaatan dan keadilan sebagai tujuan hukum yang lain.

Perjanjian utang piutang yang diikuti pula oleh perjanjian jaminan fidusia sesungguhnya merupakan perbuatan hukum yang tunduk pada hukum privat (hukum perdata) dengan kebebasan sebagai ciri utamanya, sebagaimana diatur dalam Pasal 1338 Kitab Undang undang Hukum Perdata, sebagai asas ketentuan tersebut menetapkan bahwa setiap orang memiliki kebebasan dalam membuat atau tidak membuat perjanjian, memiliki kebebasan untuk menentukan dengan siapa ia membuat perjanjian, memiliki kebebasan untuk menentukan apa yang akan diperjanjikan, memiliki pula kebebasan untuk menentukan bentuk perjanjian dan bahkan cara penyelesaian sengketanya.

Namun walau demikian harus dipahami bahwa kebebasan yang dimiliki oleh subjek hukum dalam lapangan hukum harta kekayaan tidaklah bersifat mutlak, asas kebebasan berkontrak sebagaimana ditegaskan dalam Pasal 1338 Kitab Undang undang Hukum Perdata bekerja melalui sistem ceck and balances atas asas asas yang lain, sehingga asas asas yang dikenal dan dinyatakan berlaku dengan cara mengoreksi (untuk memberikan batasan bekerjanya asas asas) dan kemudian menyeimbangkan.

Demikian pula dengan hukum jaminan sebagai bagian dari hukum benda, yang dengan berlakunya beberapa norma berlaku pula sebagai asas harus pula mampu mengoreksi (membatasi kebebasan) dan menyeimbangkan kedudukan sehingga terwujud pertukaraan hak dan kewajiban yang wajar (sebagai wujud keadilan) dan kepastian tepenuhinya hak yang dimiliki oleh kreditur, karena dengannya perjanjian sebagai sumber perikatan dan hukum sebagai pembatas dapat memberikan manfaat (memberikan kebahagiaan kepada sebanyakbanyaknya orang).

Lebih lebih jika jika yang dimaksud adalah lembaga jaminan fidusia, dengan benda bergerak sebagai objek jaminannya, hukum dituntut lebih keras bekerja untuk dapat memberikan kepastian hukum, karena potensi kehilangan objek jaminan fidusia atas benda bergerak bagi seorang kreditur lebih besar dibandingkan dengan lembaga-lembaga jaminan yang lain.

Relevan dengan hal tersebut terdapat beberapa teori berkaitan dengan cara bekerja hukum dalam pelaksanaan eksekusi objek jaminan fidusia, antara lain teori yang berkaitan dengan hukum yang berkeadilan. Keadilan sebagai teori mulanya digagas oleh Aristoteles, menurutnya pertama dalam konteks perjanjian, hukum dianggap berkeadilan jika hukum memberikan kontra prestasi yang sama pada setiap orang yang berhak tanpa memperhitungkan prestasi yang telah dilakukan, ini disebut dengan keadilan kumutatif (iustitia commutativa), dan kedua hukum (termasuk di dalamnya perjanjian) dianggap adil jika ia memberikan kontra prestasi yang sesuai dengan prestasinya, hak yang dimiliki oleh seseorang (kreditur) dan kewajiban yang dimiliki oleh seseorang (debitur) diperhitungkan secara proporsional berhak dengan cara memperhitungkan atas prestasi dan kontra prestasi 
secara proporsional, jenis keadilan ini disebut dengan keadilan distributif (iustitia distributiva).

Prinsip keadilan distributif menurut Peter Mahmud, merujuk kepada adanya persamaan di antara manusia yang didasarkan atas prinsip proporsionalitas. Dalam pandangan Gustav Radbruch di dalam upaya mewujudkan keadilan distributif, terdapat hubungan superordinasi dan subordinasi yang dimiliki oleh orang yang memiliki wewenang untuk membagi dan yang menerima bagian (antara negara sebagai pihak yang memiliki wewenang untuk membagi dan warga negara sebagai pihak yang berhak menerima bagian (perlindungan hukum). Dalam hubungan yang bersifat superordinasi untuk mewujudkan keadilan distributif Negara harus hadir untuk menentukan nilai nilai keadilan dan cara mewujudkannya, sehingga dapat memberikan perlindungan kepada warga negaranya.

Untuk melaksanakan keadilan ini (keadilan) diperlukan adanya pihak yang membagi yang bersifat superordinasi terhadap lebih dari satu orang atau kelompok orang sebagai pihak yang menerima bagian yang sama-sama memiliki kedudukan yang subordinasi terhadap yang membagi. Yang menjadi tolok ukur dalam prinsip proporsionalitas dalam kerangka keadilan distributif adalah jasa, prestasi, kebutuhan dan fungsi. Dengan adanya dua orang atau kelompok orang yang berkedudukan sama sebagai subordinat terhadap pihak yang membagi dapat dilihat apakah yang membagi telah berlaku adil berdasarkan tolok ukur tersebut. Dalam dunia nyata, pihak yang membagi adalah negara dan yang mendapat bagian adalah rakyatnya. Berdasarkan pandangan ini, dilihat dari keadilan distributif adakah suatu negara telah membuat undang-undang yang bersandar pada tolok ukur tersebut, apakah tindakan Pemerintah juga demikian dan pengadilan juga menjatuhkan putusan yang memerhatikan ukuran-ukuuran itu. ${ }^{10}$

Sedangkan yang dimaksud dengan keadilan kumutatif, menurut pandangan Aristoteles adalah keadilan yang tercipta di atas hubungan yang bersifat koordinatif di antara para pihak, sehingga kedudukan yang sama atau kedudukan yang diartikan oleh Thomas Aquinas sebagai ekuivalensi/harmoni/keseimbangan, merupakan sebuah keharusan guna mewujudkan jenis keadilan ini. 11 "Sehubungan dengan hakikat keadilan dalam kontrak, beberapa sarjana mengajukan pemikirannya tentang keadilan yang berbasis kontrak, antara lain John Locke, Rosseau, Immanuel Kant, John Rawls. Para pemikir tersebut menyadari bahwa tanpa kontrak serta hak dan kewajiban yang ditimbulkannya, maka masyarakat bisnis tidak akan berjalan. Oleh karena itu tanpa adanya kontrak, orang tidak akan bersedia terikat dan bergantung pada pernyataan pihak lain. Kontrak memberikan sebuah cara menjamin bahwa masing-masing individu akan memenuhi janjinya, dan selanjutnya hal ini memungkinkan terjadinya transaksi di antara mereka." 12

${ }^{10}$ Peter Mahmud Marzuki, 2009, Pengantar Ilmu Hukum, Kencana Prenada Media Group, Jakarta. Hlm. 152

${ }^{11}$ Ibid.

${ }^{12}$ Agus Yudha Hernoko, 2013, Hukum Perjanjian Asas Proporsionalitas dalam Kontrak Komersial, Kencana Predana Media Group, Jakarta. Hlm. 52. 
Di antara keduanya (keadilan distributif dan keadilan kumutatif) memiliki cara kerja yang berbeda, dan karenanya di antara keduanya tidak boleh dipisahkan khususnya dalam pemberlakuan hukum yang berkaitan dengan perjanjian yang mengatur secara khusus perjanjian utang piutang dan perjanjian jaminan fidusia. Karena keadilan kumutatif merupakan basis terwujudnya perjanjian yang bersifat transaksional, dan perjanjian distributif bekerja untuk membatasi dan menyeimbangkan kedudukan serta hak dan kewajiban yang lahir melalui perjanjian yang bersifat transaksional tersebut.

John Rawls menambahkan bahwa untuk mewujudkan keadilan sebagai hasil (justice), haruslah diawali dengan keadilan dalam berproses (fairness), karena dalam pandangannya keadilan (justice) sebagai hasil hanya dapat terwujud melalui proses yang adil, proses yang memenuhi prinsip fairness/procedural justice.$^{13}$ Berdasarkan teori tersebut dapat kita pahami bahwa perjanjian harus dibuat didasarkan pada keadilan kumutatif (pengakuan atas kedudukan yang sama), dalam hukum perikatan teori ini bekerja melalui asas keseimbangan, ditopang dengan keadilan prosedural/keadilan dalam berproses (fairness) dan dikontrol melalui pemberlakuan keadilan distributif (peran Negara untuk membentuk hukum yang berkeadilan yang berlaku secara memaksa (dwingen recht) bagi kontraktan melalui asas asas yang dikenal dalam hukum perikatan dan Undang undang Nomor 42 Tahun 1999 tentang Jaminan Fidusia, sehingga akan dihasilkan pertukaran hak dan kewajiban yang wajar (wujud perlindungan hukum) dan kepastian atas terpenuhinya hak kreditur.

Perlindungan hukum merupakan refleksi atas terwujudnya fungsi dan tujuan hukum, perlindungan hukum dapat diperoleh oleh subjek hukum jika fungsi dan tujuan hukum terwujud dengan baik. Berdasarkan bentuknya Philipus M. Hadjon, membedakan perlindungan hukum dalam 2 bentuk yakni perlindungan hukum preventif, hukum yang bekerja untuk mencegah terjadinya konflik/sengketa, dan perlindungan hukum represif yang bekerja untuk menyelesaikan konflik/sengketa yang sedang atau telah terjadi. ${ }^{14}$

Sejalan dengan pendapat Philipus M. Hadjon, Lili Rasjidi dan I.B. Wysa Putra menyatakan bahwa hukum seharusnya tidak hanya sekedar berfungsi untuk mewujudkan perlindungan yang bersifat adaptif dan fleksibel, tetapi hukum juga harus berfungsi secara prediktif dan antisipatif. ${ }^{15}$

Sedangkan Sunaryati Hartono menegaskan bahwa hukum bekerja memberikan perlindungan hukum karena dibutuhkan untuk melindungi kepentingan-kepentingan mereka yang lemah secara sosial, ekonomi, dan politik untuk memperoleh keadilan sosial. ${ }^{16}$

${ }^{13}$ Ibid. Hlm. 58.

${ }^{14}$ Philipus M. Hadjon, 2007, Perlindungan Hukum Bagi Rakyat Indonesia, Peradapan, Hlm.

2.

${ }^{15}$ Lili Rasjidi dan I.B. Wysa Puta, 1993. Hukum Sebagai Suatu Sistem, Remaja Rusdakarya, Bandung. Hlm. 118.

${ }^{16}$ Sunaryati Hartono, 1991. Politik Hukum Menuju Satu Sistem Hukum Nasional, Alumni, Bandung. HIm. 55. 
Sulistyandari menjelaskan bahwa perlindungan hukum dibedakan menjadi dua, yaitu perlindungan hukum dalam bidang publik dan perlindungan hukum dalam bidang perdata/privat, perlindungan hukum dalam bidang publik dapat diwujudkan melalui peran negara dalam bentuk intervensi Pemerintah secara aktif dalam kehidupan bermasyarakat, dalam pandangan penulis termasuk di dalamnya dalam kegiatan yang bersifat transaksional dalam tulisan ini konteksnya adalah perjanjian utang piutang dan perjanjian jaminan fidusia.

Peran tersebut diwujudkan dalam peraturan perundang-undangan, atau melalui keputusan-keputusan atau ketetapan-ketetapan Pemerintah yang bersifat sepihak guna mengatur dan menyelenggarakan kepentingan umum (implementasi keadilan distributif).

Dalam bentuk perlindungan ini maka erat kaitannya pula dengan bentuk perlindungan hukum preventif dalam pandangan Philipus M. Hadjon, perlindungan preventif diwujudkan dalam peraturan perundang-undangan dan bentuk keputusan-keputusan/ketetapan-ketetapan Pemerintah dan penyelesaian sengketa oleh pengadilan merupakan bentuk perlindungan represif. $^{17}$

Sedangkan perlindungan hukum dalam bidang hukum perdata, didasarkan pada prinsip kebebasan yang diberikan kepada warga negara untuk menentukan bentuk dan cara terbentuknya hubungan hukum (perjanjian) dalam batasan-batasan tertentu, yang ditopang oleh undang-undang (peraturan tertulis), hukum kebiasaan, perjanjian dan keputusan pengadilan, demikian pula dalam bentuk perlindungan hukum represif. ${ }^{18}$

\section{E. PENUTUP}

Hukum melalui instrumennya (Pasal 29 Undang undang Nomor 42 Tahun 1999 tentang Jaminan Fidusia) telah memberikan kemudahan dalam beberapa alternatif penyelesaian kredit macet dengan jalan eksekusi, dan jaminan fidusia melalui title eksekutorial yang memuat the right to reposses berdasarkan hukum (Pasal 30 Undang undang Nomor 42 Tahun 1999 tentang Jaminan Fidusia) telah memberikan wewenang kepada kreditur mengambil objek jaminan fidusia secara langsung baik dengan bantuan atau tidak dengan bantuan pihak yang berwenang, jika debitur tidak bersedia menyerahkan secara sukarela objek jaminan tersebut. Atas wewenang tersebut maka dapat diyakini Undang undang Nomor 42 Tahun 1999 tentang Jaminan Fidusia telah memberikan kepastian atas terpenuhinya hak kreditur, sehingga keadilan substansial sebagai tujuan utama dapat secara optimal dapat diwujudkan.

\section{DAFTAR PUSTAKA}

Agus Yudha Hernoko, Hukum Perjanjian Asas Proporsionalitas dalam Kontrak Komersial, Kencana Predana Media Group, Jakarta: 2013.

${ }^{17}$ Sulistyandari, 2012, Hukum perbankan Perlindungan Hukum Terhadap Nasabah Penyimpan Melalui Pengawasan Perbankan di Indonesia, Laros, Sidoarjo. Hlm. 286-287.

${ }^{18}$ Ibid. 
Benny K. Heriawanto, Isdiyana Kusuma Ayu, Efektivitas Perlindungan Hukum Pihak Pihak Dalam Pelaksanaan Eksekusi Objek Fidusia Di Kota Malang, Laporan Hasil Penelitian Program Hibah Institusi UNISMA (Hi-Ma), Lembaga Penelitian dan Pengabdian Kepada Masyarakat Universitas Islam Malang, Malang: 2018.

Dominikus Rato, Dunia Hukum Orang Osing, LaksBang Mediatama, Yogyakarta; 2009.

Gunawan Widjaja dan Ahmad Yani, Seri Hukum Bisnis Jaminan Fidusia, Rajawali Pers, Jakarta: 2000,

H. Salim, HS, Perkembangan Hukum Jaminan DI Indonesia, Rajagrafindo, Jakarta: 2004.

Lili Rasjidi dan I.B. Wysa Puta, Hukum Sebagai Suatu Sistem, Remaja Rusdakarya, Bandung: 1993.

M. Yahya Harahap, Ruang Lingkup Permasalahan Eksekusi Bidang Perdata, Edisi Kedua, Sinar Grafika, Jakarta: 2009.

P.N.H. Simanjuntak, Pokok pokok Hukum Perdata Internasional, Djambatan, Jakarta: 2009.

Pengadilan Negeri Bekasi, http://pn-bekasikota.go.id/2015-06-06-01-33-28/eksekusijaminan.html diakses pada tanggal 22 Juni 2019.

Peter Mahmud Marzuki, Pengantar Ilmu Hukum, Kencana Prenada Media Group, Jakarta; 2009.

Philipus M. Hadjon, Perlindungan Hukum Bagi Rakyat Indonesia, Peradapan, Surabaya: 2007.

Sunaryati Hartono, Politik Hukum Menuju Satu Sistem Hukum Nasional, Alumni, Bandung: 1991.

Thamrin Abdullah, Francis Tantri, Bank dan Lembaga Pembiayaan, Rajagrafindo Persada, Jakarta: 2002. 